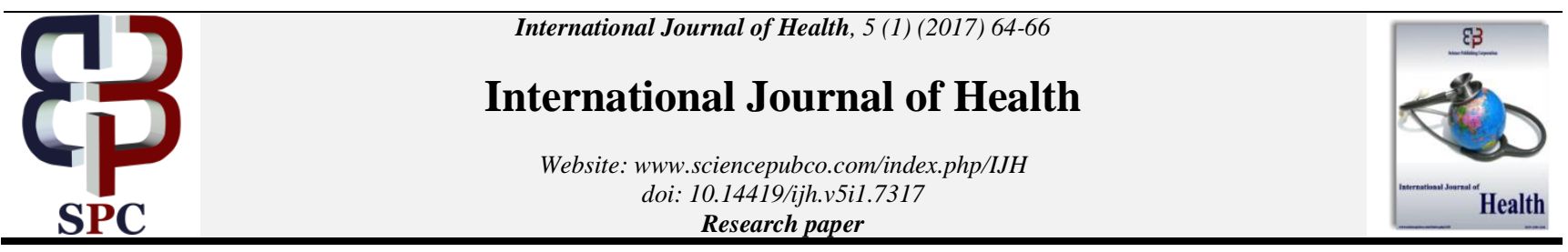

\title{
Extended spectrum beta-lactamase producing enterobacteriaceae (ESBL) isolated from herbal preparations
}

\author{
Iyekhoetin Matthew Omoruyi *, Ayomikun Oluwatosin Ogunsakin \\ Department of Basic Sciences (Microbiology option), Faculty of Basic and Applied Sciences, \\ Benson Idahosa University, P.M.B. 1100, Benin City, Edo State, Nigeria \\ *Corresponding author E-mail: iomoruyi@biu.edu.ng
}

\begin{abstract}
Herbal preparations are unsuspected sources of human exposure to pathogenic microorganisms, including those showing high resistance to antibiotics. In this study, we investigated the presence of bacteria belonging to the enterobacteriaceae family in herbal preparation and for the presence of the $\beta$-lactamase enzyme by established methods. The mean coliform and enterobacteriaceae counts ranged from $2.3 \mathrm{x}$ $10^{3}$ to $1.1 \times 10^{6} \mathrm{cfu} / \mathrm{ml}$ and $2.3 \times 10^{3}$ to $6.5 \times 10^{4} \mathrm{cfu} / \mathrm{ml}$ respectively. The organisms were further identified to belong to the genus Escherichia, Klebsiella, Citrobacter and Serratia. The antibiogramic activity shows that the bacterial isolates were mostly resistant to caftazidime, augmentin and cefuroxime. Only one of the Klebsiella specie further elicited extended spectrum beta lactamase (ESBL) activity against the cephalosporin antibiotics. There is therefore, increased need for microbiological and toxicological examination of herbal medicine to prevent outbreak of diseases.
\end{abstract}

Keywords: Enterobacteriaceae; Public Health; Herbal Medicine; E. coli; B-Lactamase.

\section{Introduction}

Herbal preparations are crude products of various kind of medicinal plants which involve the use of a whole plant or any of its parts (leaf, stem, root, flower, or seed) and are presumed to be safe for human consumption (Stević et al., 2012). The use of herbal preparations is on the increase in most developing and developed nations, with approximately $65 \%$ to $80 \%$ of the world's population depending on herbal preparations for their primary health care delivery (Barnes, 2003).

Despite the continued dependence and/or use of herbal preparations, there are reported cases of adverse health effects such as suspected carcinogenicity and/or hepatotoxicity as well as induced drug-metabolizing enzymes (Moreira et al., 2014). These effects may be due to the poor quality of herbal products or poor hygienic conditions maintained by its manufacturers, and remain a serious threat to patient hygiene (WHO, 2008). Despite the unexpected outcome with most herbal preparations, there exist controversies with the regulation, safety, and standardization of the products in different countries but in most cases, regulatory agencies are lenient regarding proof of efficacy as well as hygiene, but instead, consider long standing folk use as evidence of safety and a waiver of a thorough toxicological and microbiological evaluation (Nworu et al., 2014).

In addition to the potential toxicity of herbal preparations, they are reported to inadvertently contain different types of heavy metals in varying concentrations (Ting et al., 2013; Shaban et al., 2016). Pathogenic microorganisms, particularly the Enterobacteriaceae and multidrug resistant bacteria are also common contaminants of herbal preparations (Ting et al., 2013; Abba et al., 2009; Esimone et al., 2007). The occurrence of these organisms in herbal preparations further makes them a suitable medium and possible source of human infection. To this end, the current study was aimed at investigating the presence of bacteria belonging to the enterobacteriaceae family, and possessing the enzyme $\beta$-lactamase in herbal preparations sold in Benin City, Edo State, South-South Nigeria.

\section{Materials and methods}

\subsection{Sample collection}

Ten liquid samples of herbal preparations (LHP) with different claims were collected from four locations (Uselu Market, Oregbeni Market, Oliha Market and Oba Market) in Benin City, Edo State, Nigeria, between January and February, 2015.

\subsection{Mean Enterobacteriaceae and coliform counts}

The mean enterobacteriaceae and coliform counts were determined as previously described (Omoruyi and Orieruo, 2016). Briefly, $1 \mathrm{~mL}$ each of the serially diluted LHP was transferred to an already prepared Eosin Methylene Blue (EMB) and MacConkey agar plates in triplicate under aseptic conditions. The respective agar plates were then incubated at $37^{\circ} \mathrm{C}$ for $24 \mathrm{hrs}$. The resultant discrete colonies were counted and the mean Enterobacteriaceae counts recorded.

\subsection{Antibiotic susceptibility pattern of bacterial isolates}

The antibiogramic activities of these isolates were determined using the method described by Iyekhoetin et al. (2011). Briefly, Muller Hinton agar plates were prepared and appropriately labelled. These plates were inoculated with the standardized bacterial broth cultures by spread plate technique. The inoculated plates were left to dry for $15 \mathrm{~min}$. Commercially available antibiotic 
discs were placed at adequate distances on each of the seeded agar plates with the aid of sterile forceps under aseptic conditions. The antibiotic discs were; ciprofloxacin CPX $(5 \mu \mathrm{g})$, nitrofurantin NIT $(30 \mu \mathrm{g})$, ofloxacin OFX $(5 \mu \mathrm{g})$, cefuroxime, caftazidime CAZ (30 $\mu \mathrm{g})$, gentamicin $(10 \mu \mathrm{g})$, cefixime $(5 \mu \mathrm{g})$ and augmentin $(30 \mu \mathrm{g})$. Zones of inhibition lesser than $14 \mathrm{~mm}$ were regarded as resistant (R), zones measuring $14 \mathrm{~mm}$ to $17 \mathrm{~mm}$ were indicated as intermediate (I), while, zones of inhibition greater than $17 \mathrm{~mm}$ were reported as susceptible (S) for the respective isolates (Harley and Prescott, 2002).

\subsection{Extended spectrum $\beta$-lactamase activity (cephalo- sporin/clavulanate combination disks)}

The ESBL potential of the bacterial isolates were performed according to the method of Rawat and Nair (2010). Briefly, test isolates were exposed to the cephalosporin antibiotics; cefotaxime, ceftzidime and cefepime solely and with clavulanic acid. The elaborated inhibition zone around the cephalosporin disc combined with clavulanic acid was then compared with the zone around the disc with the cephalosporin alone. The test was reported as positive if zones of inhibition with clavulanic acid $<5 \mathrm{~mm}$ against the zone of inhibition without clauvlanic acid.

\section{Results and discussions}

Herbal preparations are continuous sources of therapeutics for humans worldwide, especially in developing countries. In addition to their therapeutic potentials, these preparations could also pose serious grave problems for its consumers with respect to their microbiological hazard. Such hazards may occur from human activities, either deliberately or inadvertently and thus contaminating the herbal product before, during or after processing, especially with the pathogenic Enterobacteriaceae. More worrisome, is the increased resistance of these potential isolates to antibiotics, particularly, the $\beta$-lactams. Thus, the current study was aimed at investigating the current situation in Benin City, Edo State, Nigeria. The results of the mean coliform and Enterobacteriaceae counts are presented in Table 1 , and ranged from $2.3 \times 10^{3} \mathrm{cfu} / \mathrm{ml}$ to 1.14 $\times 10^{6} \mathrm{cfu} / \mathrm{ml}$ and $2.3 \times 10^{3} \mathrm{cfu} / \mathrm{ml}$ to $6.5 \times 10^{4} \mathrm{cfu} / \mathrm{ml}$ respectively. Three samples (G, H and I) out of the ten investigated did not produce any Enterobacteriaceae counts (Table 1). Incidentally, all three samples with negative outcomes were obtained in sealed packaged glass bottles, as against those (7) obtained from street vendors as herbal concoctions. Six bacterial isolates were characterized and tentatively identified to their genus level, and included: 1 Escherichia, 3 Klebsiella, 1 Citrobacter and 1 Serratia.

Table 1: Mean coliform counts and mean enterobacteriaceae Counts (Cfu/mL) of Liquid Herbal Preparations

\begin{tabular}{lll}
\hline $\begin{array}{l}\text { Herbal prepa- } \\
\text { rations }\end{array}$ & $\begin{array}{l}\text { Mean coliform } \\
\text { counts on MCA } \\
\text { (cfu/ml) X } 10^{3}\end{array}$ & $\begin{array}{l}\text { Mean Enterobacteriaceae } \\
\text { counts on EMB (cfu/ml) x } 10^{3}\end{array}$ \\
\hline A & 1100.0 & 53 \\
B & 7.3 & 36 \\
C & 50 & 18 \\
D & 79 & 36 \\
E & 2.3 & 2.3 \\
F & 10 & 65 \\
G & Nil & Nil \\
H & Nil & Nil \\
I & Nil & Nil \\
J & 160 & 6.7 \\
\hline
\end{tabular}

All bacterial isolates were mostly resistant to caftazidime, augmentin and cefuroxime, but sensitive to ofloxacin, nitrofurantoin, ciprofloxacin, and exhibited intermediate sensitivity against gentamicin (Table 2). Also, only one isolate (Klebsiella 2) elicited ESBL activity especially against the cephalosporin, ceftzidime in the presence and absence of clavulanic acid (Tables 3 and 4).
Table 2: Antibiogram Profile of the Characterized Bacterial Isolates

\begin{tabular}{|c|c|c|c|c|c|c|c|c|}
\hline $\begin{array}{l}\text { Bacte- } \\
\text { rial } \\
\text { isolate }\end{array}$ & $\begin{array}{l}\text { CA } \\
Z \\
(30 \mu \\
\text { g) }\end{array}$ & $\begin{array}{l}\text { OF } \\
X \\
(5 \\
\mu g)\end{array}$ & $\begin{array}{l}\text { AUG(3 } \\
0 \mu \mathrm{g})\end{array}$ & $\begin{array}{l}\mathrm{NH}(30 \\
\mu \mathrm{g})\end{array}$ & $\begin{array}{l}\mathrm{CP} \\
\mathrm{X} \\
(5 \mu \\
\mathrm{g})\end{array}$ & $\begin{array}{l}\text { CR } \\
X \\
(30 \mu \\
g)\end{array}$ & $\begin{array}{l}\text { C } \\
\mathrm{N} \\
(2 \\
0 \\
\mu \\
\mathrm{g})\end{array}$ & $\begin{array}{l}\text { CX } \\
M \\
(5 \\
\mu g)\end{array}$ \\
\hline Serratia & $\mathrm{R}$ & $\mathrm{S}$ & $\mathrm{R}$ & $S$ & $\mathrm{~S}$ & $\mathrm{R}$ & I & $\mathrm{R}$ \\
\hline $\begin{array}{l}\text { Esche- } \\
\text { richia }\end{array}$ & $\mathrm{R}$ & S & $\mathrm{R}$ & S & S & $\mathrm{R}$ & I & S \\
\hline $\begin{array}{l}\text { Citroba } \\
\text { cter }\end{array}$ & $\mathrm{R}$ & S & $\mathrm{R}$ & S & S & $\mathrm{R}$ & I & $S$ \\
\hline $\begin{array}{l}\text { Klebsie } \\
\text { lla } 1\end{array}$ & $\mathrm{R}$ & S & $\mathrm{R}$ & S & S & $\mathrm{R}$ & I & $\mathrm{R}$ \\
\hline $\begin{array}{l}\text { Klebsie } \\
\text { lla } 3\end{array}$ & $\mathrm{R}$ & $S$ & $\mathrm{R}$ & S & S & $\mathrm{R}$ & I & $\mathrm{R}$ \\
\hline $\begin{array}{l}\text { Klebsie } \\
\text { lla } 2\end{array}$ & $\mathrm{R}$ & $\mathrm{S}$ & $\mathrm{R}$ & S & $\mathrm{S}$ & $\mathrm{R}$ & I & $\mathrm{S}$ \\
\hline
\end{tabular}

KEY: CPX: Ciprofloxacin, NH: Nitrofurantin, OFX: Ofloxacin, CRX: Cefuroxime, CAZ: Caftazidime, CN: Gentamicin, CXM: Cefixime, AU: Augmentin, S: Sensitive, I: Intermediate, R: Resistant, S: Sensitive, I: Intermediate

Table 3: Extended spectrum $\beta$-lactamase activity ( $\mathrm{mm}$ ) of bacterial isolates in the Absence of clavulanic Acid.

\begin{tabular}{llll}
\hline Isolate & Cefotaxime & Ceftzidime & Cefepime \\
\hline Klebsiella 1 & 0 & 11 & 29 \\
Klebsiella 2 & 24 & 15 & 30 \\
Serratia & 0 & 0 & 27 \\
Escherichia & 2 & 0 & 30 \\
Citrobacter & 29 & 0 & 35 \\
Klebsiella 3 & 5 & 1 & 37 \\
\hline
\end{tabular}

KEY:Inhibitory zones $>5 \mathrm{~mm}$ indicates ESBL activity

Table 4: Extended spectrum $\beta$-lactamase activity $(\mathrm{mm})$ of bacterial isolates in the Presence of clavulanic Acid.

\begin{tabular}{llll}
\hline Isolates & Cefotaxime & ceftzidime & Cefepime \\
\hline Klebsiella 1 & 0 & 11 & 28 \\
Klebsiella 2 & 27 & 24 & 33 \\
Serratia & 0 & 0 & 31 \\
Escherichia & 2 & 0 & 31 \\
Citrobacter & 29 & 0 & 35 \\
Klebsiella 3 & 8 & 1 & 37 \\
\hline
\end{tabular}

KEY: Inhibitory zones $>5 \mathrm{~mm}$ indicates ESBL activity

The detection of lactose fermenting and non-lactose members of the Enterobacteriaceae in seven of the sampled liquid herbal drugs is a worrisome phenomenon as the presence of these Gram negative bacteria especially the faecal coliform is suggestive of poor sanitary conditions under which these drugs are processed.

Also disturbing is the fact that all the liquid herbal medicinal preparations examined in this study had no indication of both the manufacturing and expiring dates. Therefore, it was difficult to ascertain whether the herbal concoctions were within their appropriate safe use period during the sampling time. The potential sources of bacterial contamination of these hawked herbal preparations could be the sanitary state of the personnel or manufacturer(s) as potential pathogen could be introduced as well as unhygienic environment where herbal products are produced. Nakajima et al. (2005) reported that the presence of microbial contaminants in herbal preparations could reduce or even inactivate the therapeutic activity of the products and has the potential to adversely affect patient taking the medicine. Similarly, Bauer (1998) reported that in order to improve the microbiological safety of herbal preparations, there is need to observe basic hygiene practices during preparation. Also, standardization of some physical characteristics such as moisture content and $\mathrm{pH}$, and the assessment of microbiological contamination levels are desirable (Bauer, 1998). Herbal preparations in Nigeria have previously been reported to be contaminated mainly by Gram positive bacteria. In one of such studies, Oleghe et. al. (2011) isolated Staphylococcus aureus and Corynebacterium diphtheria from different herbal preparations sourced from different states in Nigeria.

The isolation of Escherichia from LHP is similar to the report of Abba et al. (2008) who reported E. coli in powdered herbal medic- 
inal preparations sourced from several herbal retail outlets in different parts of Kaduna metropolis, Northern Nigeria. The isolation of Klebsiella sp is also in keeping report with the report of Onyambu et al. (2013). In that study, they observed the presence of this bacterium in unregistered herbal drugs sold in five Kenyan provinces (Nairobi, Central, Rift Valley, Nyanza and Western). Antibiotic susceptibility study on the Gram negative bacterial contaminants of the herbal products indicated that the isolates exhibited multiple drug resistance as they were mostly resistant to at least three of the antibiotics; Caftazidime, augmentin and cefuroxime. This trend could suggest the widespread distribution of antibiotic resistant bacteria in locally prepared herbal formulations and is in contrast with the observation by Edberg et al. (1986). The expressed ability of the Gram negative bacterial isolates cultured from the herbal formulations to elicit extended spectrum $\beta$ lactamase (ESBL) activity is both novel and of public health relevance. Rupp and Fey (2003) reported that ESBLs are clinically significant and patients infected with ESBL-producing Enterobacteriaceae experience a greater likelihood of poor outcome if they are treated with inappropriate antibiotics. The authors also stated that ESBL-producing Enterobacteriaceae have been responsible for numerous outbreaks of infection throughout the world and pose challenging infection control measures.

\section{Conclusion}

The study revealed the presence of viable and culturable ESBL producing Enterobacteriaceae in seven of the ten sampled liquid herbal preparations. Consumption of these contaminated drugs could result in the development of infections especially in immunocompromised individuals. There is therefore, increased need for microbiological and toxicological examinations to prevent the outbreak of diseases.

\section{Acknowledgement}

We are grateful to Frances Olisaka for helping with practical issues during the course of the research

\section{Conflict of interest}

The authors declare that there are no potential conflicts of interest
Benin City. European Journal of Scientific Research. 52(2): 226235.

[8] Moreira, D.L., Teixeirra, S.S., Monteiro, M.H., De-Oliveira, A.C and Paumagartten, F.J.R. (2014). Traditional use and safety of herbal medicines. Revista Brasileirade Farmacognosia. 24(2): 1-6.

[9] Nakajima, K., Nonaka, K.., Yamamoto, K., Yamaguchi, N., Tani, K. and Nasu, M. (2005). Rapid monitoring of microbial contamination on herbal medicines by fluorescent staining method. Letters $\begin{array}{lllll}\text { in } \quad \text { Applied } & \text { Microbiology } 40 & \text { (2): } & 128-132 .\end{array}$ https://doi.org/10.1111/j.1472-765X.2004.01643.x.

[10] Nworu, C. S., Vin-Anuonye, T., Okonkwo, E. T., Oyeka, C. O., Okoli, U. B., Onyeto, C. A., Mbaoji F. N., Nwabunike, I. andAkah, P. A. (2014). Unregulated promotion and sale of herbal remedies: A safety and efficacy evaluation of twelve such commercial products claimed to be beneficial and patronized for a variety of ailments in Nigeria. Journal of Pharmacovigilance S1: 002 https://doi.org/10.4172/2329-6887.

[11] Oleghe, P. O., Odimegwu, D. C., Udofia, E. andEsimone, C. O. (2011). Multi-drug-resistant bacteria isolates recovered from herbal medicinal preparations in a southern Nigerian setting. Journal of Rural and Tropical Public Health10:70 - 75.

[12] Omoruyi, I.M. and Orieruo, U.A. (2016). Shiga-toxin producing Escherichia coli (STEC) and other enterobacteriaceae associated with ready-to-eat salad. International Journal of Biological Research. 4(2): 211-214.

[13] Onyambu, M. O., Chepkwony, H. K., Thoithi, G. N., Ouya, G. O. and. Osanjo, G. O. (2013). Microbial quality of unregulated herbal medicinal products in Kenya.African Journal of Pharmacology and Therapeutics 2(3):70-75.

[14] Rawat, D. and Nair, D. (2010). Extended spectrum beta lactamases in Gram negative bacteria. Journal of Global Infectious Disease. 2(3): 263-274. https://doi.org/10.4103/0974-777X.68531.

[15] Rupp, M. E. and Fey, P. D. (2003).Extended Spectrum $\beta$-Lactamase (ESBL)-Producing Enterobacteriaceae, considerations for diagnosis, prevention and drug treatment. Drugs 63 (4): 353-365 https://doi.org/10.2165/00003495-200363040-00002.

[16] Shaban, N.S., Abdou, K.A., Hassan, N.E.Y. (2016). Impact of toxic heavy metals and pesticide residues in herbal products. Beni-suef Journal of Basic and Applied Sciences. 5(1):102-106.

[17] Stević, T., Pavlović, S., Stanković, S. and Šavikin, K. (2012). Pathogenic microorganisms of medicinal herbal drugs. Archives of Bio$\begin{array}{lllll}\text { logical } & \text { Science. } & 64 & \text { (1): } & 49-58 .\end{array}$ https://doi.org/10.2298/ABS1201049S.

[18] Ting, A., Chow, Y. and Tan, W. (2013). Microbial and heavy metal contamination in commonly consumed traditional Chinese herbal medicine. Journal of Traditional Chinese Medicine. 33(1): 119124. https://doi.org/10.1016/S0254-6272(13)60112-0.

[19] World Health Organization (WHO) (2008) Traditional medicine. Fact Sheet No. 134

\section{References}

[1] Abba, D., Inabo, H. I., Yakubu, S. E. and Olonitola, O. S. (2009) Contamination of herbal medicinal products marketed in Kaduna Metropolis with selected pathogenic bacteria. African Journal of Traditional, Complementary and Alternative Medicines 6: 70-77.

[2] Barnes, J. (2003). Quality, efficacy and safety of complementary medicines: fashions, facts and the future. Part1: Regulation and quality. British Journal of Clinical Pharmacology 55: 226-233. https://doi.org/10.1046/j.1365-2125.2003.01810.x.

[3] Bauer R. (1998). Quality criteria and standardization of phytopharmaceuticals: Can acceptable drugs standard be achieved? Drugs Information Journal 32: 101-110. https://doi.org/10.1177/009286159803200114.

[4] Edberg, S.C., Piscitteli, V. and Cortter, M. (1986). Phenotypic characteristics of coliform bacteria from public water supply compared with regional and clinical species. Applied Environmental Microbiology 52 (3): $474-478$.

[5] Esimone, C. O., Oleghe, P. O., Ibezim, E. C., Okeh, C. O. and Iroha, I. R. (2007). Susceptibility-resistance profile of microorganisms isolated from herbal medicine products sold in Nigeria. $\begin{array}{llll}\text { African Journal of Biotechnology } 6 & \text { (24):2766-2775. }\end{array}$ https://doi.org/10.5897/AJB2007.000-2442.

[6] Harley, J. P. and Prescott, L.M. (2002).Laboratory Exercises in Microbiology. $5^{\text {th }}$ Edn. Mac Graw Hill, New York, 449 pp.

[7] Iyekhoetin, O.M., Nnanna, I.I., Blessing, O.I. and Idowu, B.O. (2011). Antibiograms and mutagenicity evaluation of hospital wastewaters from University of Benin Teaching Hospital (UBTH), 